\title{
EXPERIMENTAL PREPARATION OF SHORT-CARBON-FIBER-REINFORCED Al-5Cu MATRIX COMPOSITES USING VACUUM SUCTION CASTING
}

\author{
EKSPERIMENTALNA IZDELAVA S KRATKIMI OGLJIKOVIMI \\ VLAKNI OJAČANEGA KOMPOZITA S KOVINSKO MATRICO Z \\ UPORABO LIVARSKE TEHNIKE VAKUUMSKEGA ČRPANJA \\ TALINE
}

\author{
Xingqian Dong, Tao He*, Yuanming Huo, Anna Sun \\ School of Mechanical and Automotive Engineering, Shanghai University of Engineering Science, No.333 Longteng Road, \\ Shanghai 201620, China \\ Prejem rokopisa - received: 2019-09-10; sprejem za objavo - accepted for publication: 2020-06-17
}

doi:10.17222/mit.2019.217

\begin{abstract}
Carbon-fiber-reinforced aluminum matrix composites have been widely used in many industrial fields. The carbon-fiber content and elements content of $\mathrm{Mg}$ and Si has a significant influence on the performance of composites. It is vital to study the effects of the carbon-fiber content and elements content of $\mathrm{Mg}$ and $\mathrm{Si}$ on mechanical and electrical properties of composites. Short-carbon-fiber-reinforced $\mathrm{Al}-5 \mathrm{Cu}$ alloy composites $(\mathrm{Cf} / \mathrm{Al}-5 \mathrm{Cu})$ were prepared by vacuum suction casting (VSC) in this work. The mechanical and electrical properties of $\mathrm{Cf} / \mathrm{Al}-5 \mathrm{Cu}$ were measured by testing machines, and the microstructures were observed and analyzed using a scanning electron microscope (SEM). Experimental results show that the mechanical and electrical properties of the $\mathrm{Cf} / \mathrm{Al}-5 \mathrm{Cu}$ composites increase with the increase of the carbon-fiber content. The tensile strength of Cf/Al-5Cucomposites with $2 w / \%$ carbon-fiber content reached $258.7 \mathrm{MPa}$. Its microhardness reached $112.6 \mathrm{HV}$, and the resistivity was $26.5 \mu \Omega / \mathrm{mm}$. The mechanical properties of the $\mathrm{Cf} / \mathrm{Al}-5 \mathrm{Cu}$ composites can be improved by adding the elements $\mathrm{Mg}$ and $\mathrm{Si}$. When the $\mathrm{Mg}$ content is $0.3 \%$, the tensile strength of Cf/Al-5Cu composites reached 294.7 MPa, the microhardness reached $128.3 \mathrm{HV}$, and the resistivity was $18.4 \mu \Omega / \mathrm{mm}$. Adding $\mathrm{Mg}$ was more effective for the electrical properties than Si. Keywords: vacuum suction casting, carbon fiber, aluminum matrix composite, microstructure observation, properties test
\end{abstract}

Z ogljikovimi vlakni ojačani kompoziti z matrico iz Al zlitin se veliko uporabljajo na različnih področjih. Vsebnost ogljikovih vlaken in legirnih elementov, kot sta: $\mathrm{Mg}$ in $\mathrm{Si}$, imajo pomemben vpliv na lastnosti kompozitov. Zato je pomembno študirati njihov vpliv na mehanske in električne lastnosti. Avtorji v raziskavi opisujejo izdelavo in lastnosti Al-5Cu kompozita, ojačanega s kratkimi ogljikovimi vlakni (Cf/Al-5Cu). Kompozit so izdelovali z livarsko tehniko vakumskega črpanja taline (VSC; angl.: vacuum suction casting). Določili so njegove mehanske in električne lastnosti ter opazovali in analizirali njegovo mikrostrukturo s pomočjo vrstičnega elektronskega mikroskopa (SEM). Eksperimentalni rezultati so pokazali, da se mehanske in električne lastnosti Cf/Al-5Cu kompozita povišujejo s povečevanjem deleža kratkih ogljikovih vlaken. Natezna trdnost $\mathrm{Cf} / \mathrm{Al}-5 \mathrm{Cu}$ kompozita z 2 mas.\% ogljikovih vlaken, je 258,7 MPa. Njegova mikrotrdota je bila 112,6 HV in električna upornost je bila 26,5 $\mu \Omega / \mathrm{mm}$. Mehanske lastnosti Cf/Al-5Cu so izboljšali z dodatkom Mg in Si. Pri vsebnosti Mg je 0,3 mas. \% je bila natezna trdnost kompozita $294,7 \mathrm{MPa}$, mikrotrdota $128,3 \mathrm{HV}$ in električna upornost $18,4 \mu \Omega / \mathrm{mm}$. Vpliv dodatka Mg na električne lastnosti je ugodnejši kot dodatek Si.

Ključne besede: vakuumsko črpalno litje, ogljikova vlakna, kompozit s kovinsko matrico iz Al zlitine, opazovanje mikrostrukture, testi lastnosti

\section{INTRODUCTION}

Carbon-fiber-reinforced aluminum matrix composites have broad applications in many fields, such as aerospace, automotive and mechanical engineering, ${ }^{1}$ due to there high strength with light weight, high fracture toughness and good electrical and thermal conductivity. ${ }^{2,3}$ Traditional preparation methods for carbon-fiber-reinforced aluminum matrix composites were subdivided into two categories: the liquid-state method and the solid-state method. ${ }^{4}$ The typical liquid-state methods include: agitating casting, ${ }^{5}$ extrusion casting, ${ }^{6}$ vacuum pressure infiltration, ${ }^{7}$ liquid-solid extrusion following

*Corresponding author's e-mail:

hetao@sues.edu.cn (Tao He) vacuum infiltration, ${ }^{8}$ and so on. ${ }^{9,10}$ VSC has a similar forming principle to the agitating casting method, which can be applied to prepare a carbon-fiber-reinforced aluminum matrix composite. Although VSC can make sure of the rapid filling and strong plasticity, the interfacial bond strength between the carbon fiber and the matrix need to be focused on. Some material defects such as fiber pull-out and holes can emerge at the interface of the carbon fiber and the matrix.

Many researchers stated that these defects could be effectively reduced by selecting the appropriate process parameters and adding $\mathrm{Si}$ and $\mathrm{Mg}$ to the aluminum alloy matrix. Z. G. Liu et al. ${ }^{11}$ prepared $\mathrm{Cf} / \mathrm{Al}$ materials by extrusion casting. The results show that the carbon fibers changed the solidification structure of the Al-Cu matrix 
alloys. S. R. Bakshi. et al. ${ }^{12}$ analyzed the influence of the addition of $\mathrm{Si}$ and $\mathrm{Mg}$ on the interfacial reaction of the aluminum-based alloy matrix by TEM observation- C. Wang et al. ${ }^{13}$ studied the effect of $\mathrm{Mg}$ content on the $\mathrm{Cf} / \mathrm{Al}$ interface prepared using the pressure-infiltration method. Few publications can be found about the preparation of carbon-fiber-reinforced aluminum matrix composites using VSC, and the effect of carbon fiber content and $\mathrm{Mg}$ and $\mathrm{Si}$ on the composites was seldom reported.

The aim of this work is to prepare the $\mathrm{Cf} / \mathrm{Al}-5 \mathrm{Cu}$ using the VSC method. Firstly, experiments were conducted to prepare composites with different carbon-fiber contents and different $\mathrm{Mg}$ and $\mathrm{Si}$ contents using the VSC technique. Secondly, the effects of carbon-fiber content and $\mathrm{Mg}$ and Si content on the microstructure, mechanical and electrical properties of aluminum alloy were studied. The reinforcing effect of carbon fiber on aluminum-based composites under different conditions was analyzed. Finally, good performance was obtained by optimizing the parameters of the carbon-fiber content and the $\mathrm{Mg}$ and Si content.

\section{EXPERIMENTAL MATERIALS AND METHODS}

\subsection{Experimental procedure}

$\mathrm{Al}-5 \mathrm{Cu}$ was selected as the matrix of the composite material. The T-1000 short carbon fiber (Cf) was selected as the reinforcing term. In order to study the effects of carbon-fiber content and elements content of $\mathrm{Mg}$ and $\mathrm{Si}$ on the material properties, the chemical compositions of the composite materials were listed in Table $\mathbf{1 .}$ Nine different specimens were prepared in this section.

Table 1: The chemical composition of the composite materials (in mass fractions $(w / \%)$

\begin{tabular}{|c|c|c|c|c|}
\hline Number & Carbon fiber & $\mathrm{Mg}$ & $\mathrm{Si}$ & $\mathrm{Al}-5 \mathrm{Cu}$ \\
\hline 1 & 0 & 0 & 0 & Bal. \\
\hline 2 & 1 & 0 & 0 & Bal. \\
\hline 3 & 2 & 0 & 0 & Bal. \\
\hline 4 & 1 & 0.1 & 0 & Bal. \\
\hline 5 & 1 & 0.2 & 0 & Bal. \\
\hline 6 & 1 & 0.3 & 0 & Bal. \\
\hline 7 & 1 & 0 & 0.1 & Bal. \\
\hline 8 & 1 & 0 & 0.2 & Bal. \\
\hline 9 & 1 & 0 & 0.3 & Bal. \\
\hline
\end{tabular}

Short-carbon-fiber-reinforced aluminum matrix composites $(\mathrm{Cf} / \mathrm{Al}-5 \mathrm{Cu})$ were prepared by $\mathrm{VSC}$. VSC is a precision casting process, which was completed by the coupling of gravity and suction under a high differential pressure. ${ }^{14,15}$ This method has three advantages. First, the entire casting process was carried out under high vacuum, effectively avoiding the problem of alloy oxidation and impurity doping. Secondly, non-contact magnetic stirring can avoid the metal pollution caused by mechanical stirring. Finally, the use of suction coupled with gravity increases the speed and success rate of traditional gravity casting. This method can be well applied to the preparation of composite materials. The process parameters of VSC are shown in Table 2.

Table 2: Process parameters to prepare $\mathrm{Cf} / \mathrm{Al}-5 \mathrm{Cu}$ composites by VSC

\begin{tabular}{|c|c|c|c|c|}
\hline $\begin{array}{c}\text { Vacuum } \\
\text { degree } \\
(\mathrm{Pa})\end{array}$ & $\begin{array}{c}\text { Melting } \\
\text { temperature } \\
\left({ }^{\circ} \mathrm{C}\right)\end{array}$ & $\begin{array}{c}\text { Smelting } \\
\text { current } \\
(\mathrm{A})\end{array}$ & $\begin{array}{c}\text { Suc- } \\
\text { tion-hole } \\
\text { diameter } \\
(\mathrm{mm})\end{array}$ & $\begin{array}{c}\text { Casting } \\
\text { pressure } \\
(\mathrm{MPa})\end{array}$ \\
\hline $8 \times 10^{-4}$ & $750 \approx 800$ & 0.15 & 3.5 & 0.65 \\
\hline
\end{tabular}

Experiments were carried out on a VSC machine. A schematic diagram of the equipment is shown in Figure1. The experimental steps were as follows:

1) The aluminum alloy of $\mathrm{Al}-5 \mathrm{Cu}$ and short carbon fibers were placed in the melting crucible of the VSC equipment. Then, the cover was closed, and the vacuum chamber and the suction chamber were evacuated, and filled with a certain pressure of argon gas to make sure of the stability.

2) The arc gun was used to heat the aluminum alloy of $\mathrm{Al}-5 \mathrm{Cu}$ and short carbon fibers in the melting crucible. After the aluminum matrix material became a molten state, the electromagnetic stirring device was used to stir molten material with a rotating electromagnetic field until the short carbon fibers were uniformly distributed in the aluminum alloy matrix. It is experimentally observed that carbon fibers can be uniformly incorporated into metal liquids under the action of a magnetic stirring force, instead of floating on metal surfaces.

3) The carbon-fiber-reinforced aluminum matrix composite of the well-mixed molten state was transformed into the casting crucible by the manipulator. Opening the suction casting valve, a negative pressure difference was created between the vacuum chamber and the suction chamber. The well-mixed molten state composite passed through the graphite suction hole between the two chambers. It quickly filled into a copper mould under the effect of gravity and negative pressure difference. In order to improve the microstructure of the specimens, radial pressurization was conducted. A pressure of

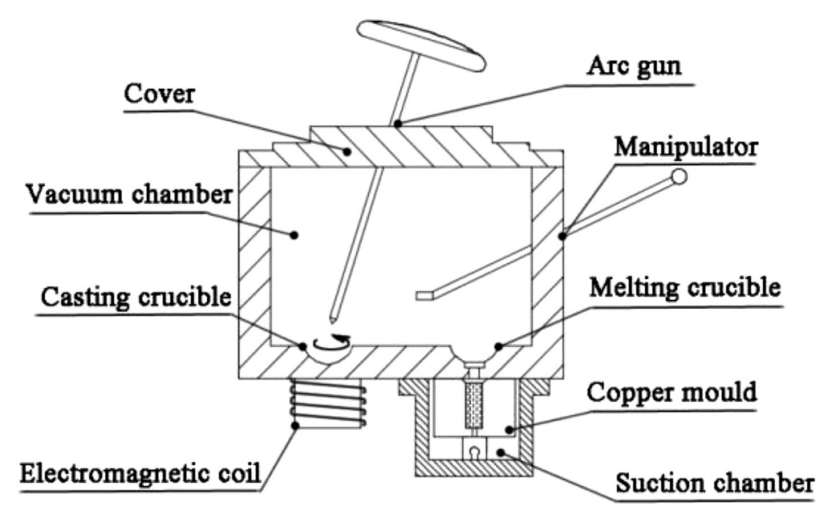

Figure 1: Schematic diagram of VSC equipment 


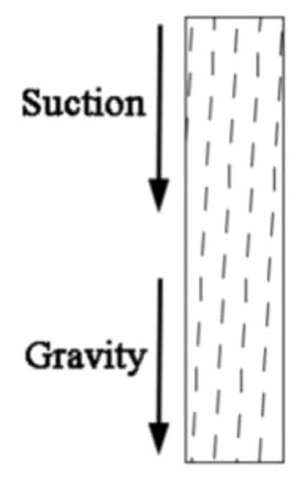

(a)

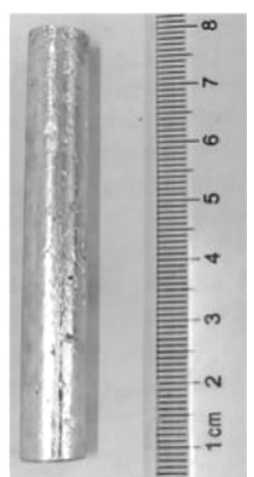

(b)
Figure 2: a) Schematic diagram of $\mathrm{Cf} / \mathrm{Al}-5 \mathrm{Cu}$ composites and b) the specimen of the $\mathrm{Cf} / \mathrm{Al}-5 \mathrm{Cu}$ composites

$4 \mathrm{MPa}$ was applied and held for $1 \mathrm{~min}$. The pressure was applied repeatedly 6 times. The well-mixed molten state composite was solidified due to cooling of the copper mould, and the carbon fibers were evenly arranged along the axial direction of the casting, shown in Figure 2a.

4) The T5 heat treatment was carried out for prepared specimens. ${ }^{16,17}$ It was held at $515{ }^{\circ} \mathrm{C}$ for 6 husing a box-type resistance furnace and then quenched with water at $50{ }^{\circ} \mathrm{C}$. Thereafter, solution treatment was carried out, and the mixture was kept at $175^{\circ} \mathrm{C}$ for $5 \mathrm{~h}$, and then cooled and molded at room temperature. The specimens of $\mathrm{Cf} / \mathrm{Al}-5 \mathrm{Cu}$ composites were obtained shown in Figure $2 \mathbf{b}$.

\subsection{Property tests and microstructure observation}

Property tests include measuring the microhardness, measuring tensile strength and measuring electrical performance. The tensile strength of the composite material was measured using the JVJ-50s microcomputer-controlled electronic universal testing machine. The microhardness of the specimen was measured using an MHVD-1000IS image analysis multi-function digital microhardness tester. In the electrical performance tests,

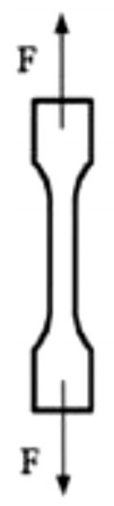

(a)

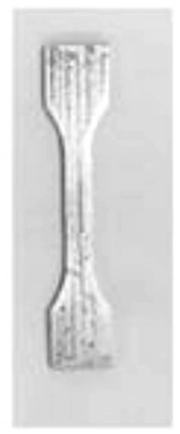

(b)

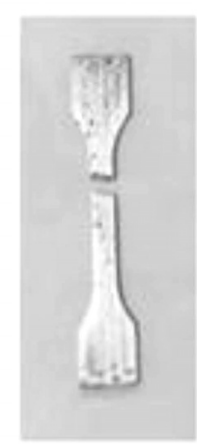

(c)
Figure 3: The tensile specimen the resistivity of the material was measured using a FT300 resistivity tester. The standard test samples were machined using a wire cutting machine. And then, the test pieces were grinded with a abrasive paper to remove the stress concentration generated by the wire-cutting process. Figure 3 shows a tensile specimen. The tensile specimens were stretched to failure.

Before the microstructure observation, the specimens were sectioned, grinded by $800 \#, 1000 \#$, $2000 \#$ waterproof abrasive paper and polished on a polishing machine. The polished surface was etched using an acidic solution $\left(2 \mathrm{~mL} \mathrm{HF}+3 \mathrm{~mL} \mathrm{HCl}+5 \mathrm{~mL} \mathrm{HNO}_{3}+190 \mathrm{~mL}\right.$ $\mathrm{H}_{2} \mathrm{O}$ ). Then, the polished surface was cleaned using alcohol and dried with a hair drier. The microstructures of the $\mathrm{Cf} / \mathrm{Al}-5 \mathrm{Cu}$ composites were observed using a SM-6700F SEM.

\section{EXPERIMENTAL RESULTS AND DISCUSSION}

\subsection{Effect of carbon-fiber content on the mechanical and electrical properties}

Figure 4 shows the microhardness of the $\mathrm{Cf} / \mathrm{Al}-5 \mathrm{Cu}$ composites under different carbon fiber contents. It can be seen that the microhardness of the $\mathrm{Cf} / \mathrm{Al}-5 \mathrm{Cu}$ composites increases with the increase of the carbon fiber content. The microhardness of the $\mathrm{Cf} / \mathrm{Al}-5 \mathrm{Cu}$ composites was $112.6 \mathrm{HV}$ under a carbon fiber of $2 \mathrm{w} / \%$. Compared with the original alloy without carbon fiber, the microhardness increased by $26.1 \%$ under carbon fiber of $2 w / \%$.

The tensile strength of the $\mathrm{Cf} / \mathrm{Al}-5 \mathrm{Cu}$ composites under different carbon fiber content is shown in Figure 5. It can be seen that the tensile strength of the Cf/Al-5Cu composites increases with the increase of the carbon fiber content. The Cf/Al-5Cu composites with 2 w/\% carbon fiber content had a tensile strength of $258.7 \mathrm{MPa}$, which is higher than that of the original aluminum alloy of about $26.1 \%$. As the carbon-fiber content increases, the number of carbon fibers contained in the matrix in-

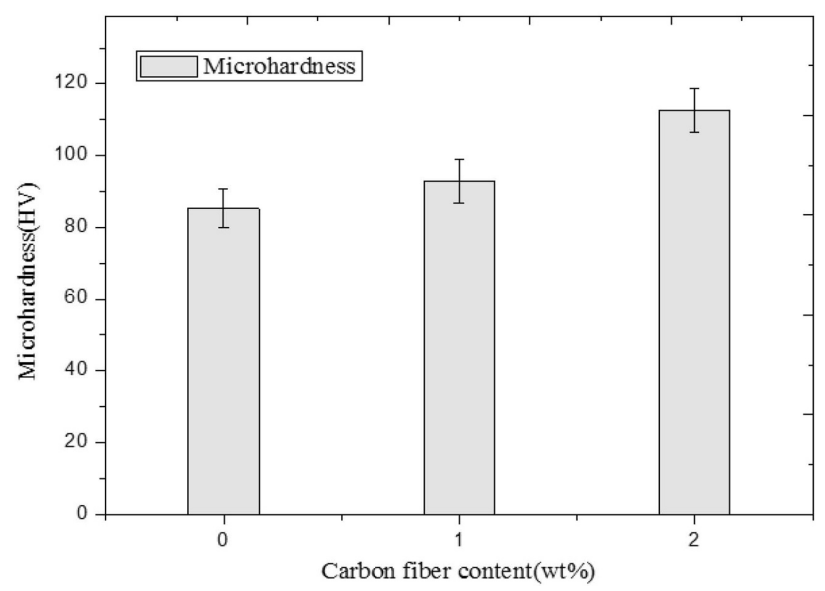

Figure 4: Microhardness of $\mathrm{Cf} / \mathrm{Al}-5 \mathrm{Cu}$ composites with different carbon-fiber contents 


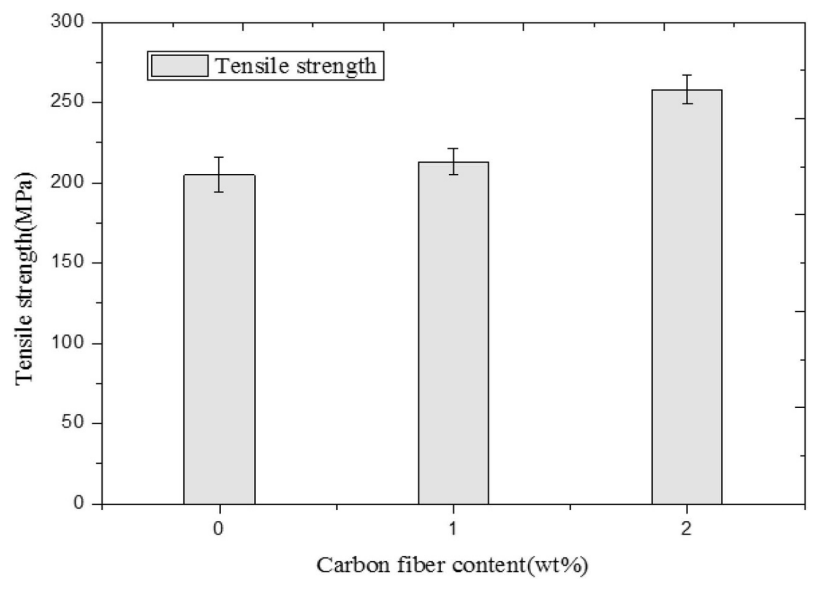

Figure 5: Tensile strength of $\mathrm{Cf} / \mathrm{Al}-5 \mathrm{Cu}$ composites with different carbon-fiber contents

creases. The more the number of carbon fibers, the more obvious the increase of the bearing capacity. So, the mechanical properties of the $\mathrm{Cf} / \mathrm{Al}-5 \mathrm{Cu}$ composites are improved. However, due to the difference in the elastic modulus between the carbon fiber and the base aluminum alloy, the interface bonding between the matrix alloy and the carbon fiber was restrained. This limited the reinforcing effect of the carbon fiber.

The resistivity of the $\mathrm{Cf} / \mathrm{Al}-5 \mathrm{Cu}$ composites is shown in Figure 6. It can be seen that the resistivity of the $\mathrm{Cf} / \mathrm{Al}-5 \mathrm{Cu}$ composites decreases with the increase of the carbon fiber content. When the carbon fiber content is $1 \mathrm{w} / \%$, the average volume resistivity of the composites is $28.6 \mu \Omega / \mathrm{mm}$. This resistivity increases by $31.2 \%$ compared to the original matrix of $21.8 \mu \Omega / \mathrm{mm}$. When the carbon fiber content is $2 w / \%$, the resistivity of the composite is $26.5 \mu \Omega / \mathrm{mm}$. The resistivity of the material is reduced by $6.8 \mu \Omega / \mathrm{mm}$ compared to the $1 w / \%$ $\mathrm{Cf} / \mathrm{Al}-5 \mathrm{Cu}$ composites.

This is because the higher the fiber content, the easier the fibers overlap each other. It is more conducive to the

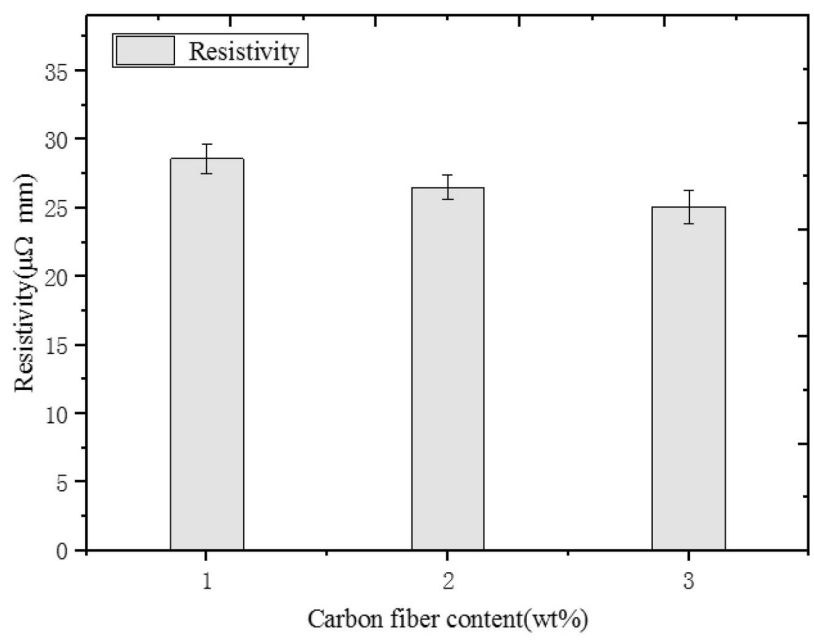

Figure 6: Resistivity of $\mathrm{Cf} / \mathrm{Al}-5 \mathrm{Cu}$ composites with different carbon-fiber contents formation of conductive paths. Thereby, it can reduce the volume resistivity of the conductive composite. Within a certain range, a higher conductive carbon composite can be obtained by adding a higher carbon-fiber content.

\subsection{Effect of elements content on mechanical and elec- trical properties}

Since the surface energy of $\mathrm{Si}$ and $\mathrm{Mg}$ is lower than that of $\mathrm{Al}$, the addition of $\mathrm{Si}$ and $\mathrm{Mg}$ can reduce the surface tension of the aluminum alloy matrix. $\mathrm{Mg}$ and $\mathrm{Si}$ can improve the wettability between the carbon fiber and the aluminum alloy matrix, ${ }^{18}$ and improve the interfacial bonding. In the study, different contents of $\mathrm{Mg}$ and $\mathrm{Si}$ were added into the $\mathrm{Cf} / \mathrm{Al}-5 \mathrm{Cu}$ alloy with $1 \mathrm{w} / \%$ carbon fiber. And the mechanical and electrical properties of the composites were measured.

The microhardness of the composites with different $\mathrm{Mg}$ and $\mathrm{Si}$ contents is shown in Figure 7. It can be seen that both $\mathrm{Mg}$ and $\mathrm{Si}$ can improve the microhardness of the $\mathrm{Cf} / \mathrm{Al}-5 \mathrm{Cu}$ composites. The effect of $\mathrm{Mg}$ on material properties is more obvious than that of Si. The microhardness increases with the increase of the element content. The microhardness of the $\mathrm{Cf} / \mathrm{Al}-5 \mathrm{Cu}$ composites after adding $0.3 \% \mathrm{Si}$ element was $96.1 \mathrm{HV}$. With the addition of the same amount of $\mathrm{Mg}$, the hardness was increased to $128.3 \mathrm{HV}$, which was higher than that of the same amount of Si-added material by about $33.5 \%$.

The tensile strength of the composites with different $\mathrm{Mg}$ and Si contents is shown in Figure 8. It can be seen that the addition of Si has no obvious effect on the tensile strength. The improvement effect of $\mathrm{Mg}$ is better than that of $\mathrm{Si}$ element. The addition of $\mathrm{Mg}$ element can effectively improve the tensile strength of the composites. When $0.3 \% \mathrm{Mg}$ is added, the tensile strength of the composites is increased to $294.7 \mathrm{MPa}$. The composite material obtained by adding the same amount of $\mathrm{Si}$ is 213.3 $\mathrm{MPa}$, while the tensile strength was reduced by $38.2 \%$.

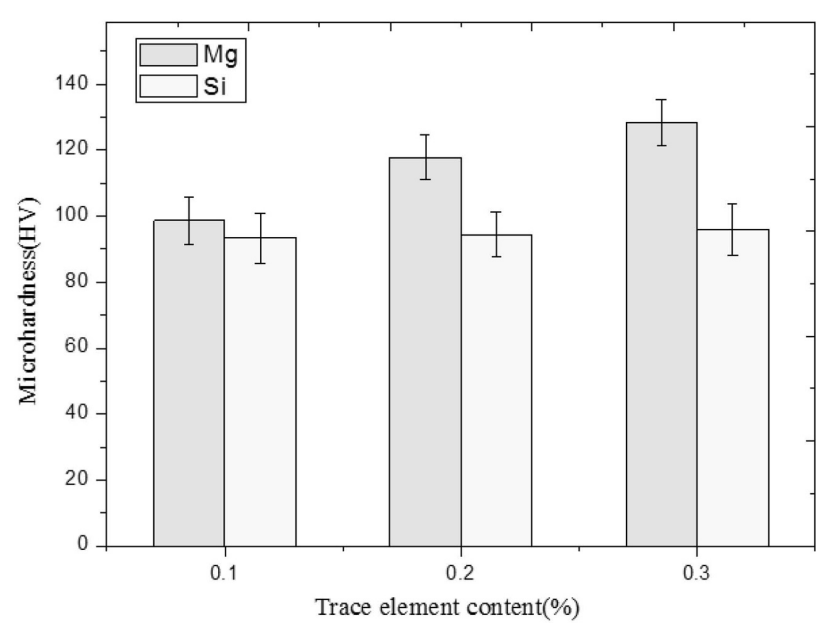

Figure 7: Microhardness of $\mathrm{Cf} / \mathrm{Al}-5 \mathrm{Cu}$ composites with different $\mathrm{Mg}$ and $\mathrm{Si}$ contents 


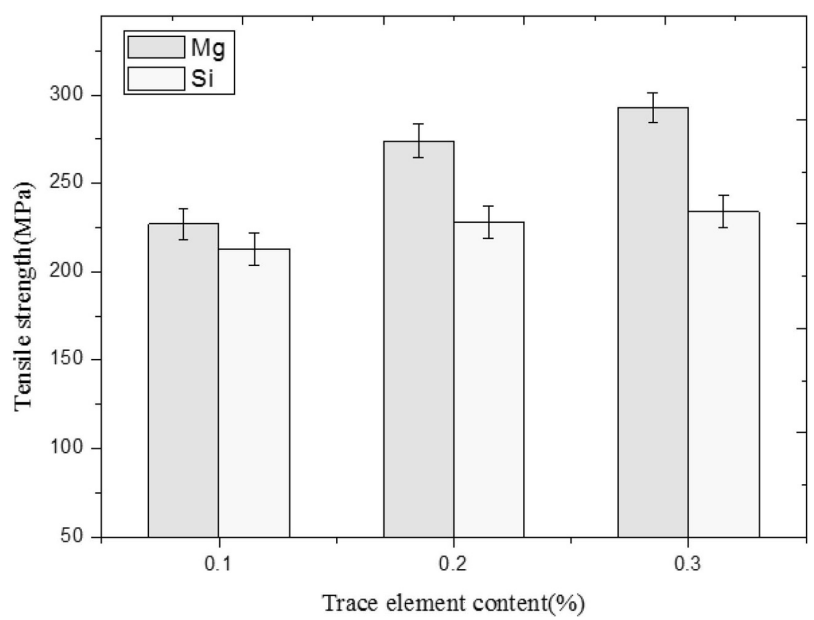

Figure 8: Tensile strength of $\mathrm{Cf} / \mathrm{Al}-5 \mathrm{Cu}$ composites with different $\mathrm{Mg}$ and $\mathrm{Si}$ contents

This is mainly because the strengthening mechanism of $\mathrm{Mg}$ to the material is solid-solution strengthening. It is beneficial to improving the wettability between the carbon fiber and the alloy matrix, and reducing the harmful substances formed on the surface of the carbon fiber. Therefore, the addition of $\mathrm{Mg}$ can improve the mechanical properties of the material. However, Si belongs to the second phase in the composite material. Si does not work on the interface. Therefore, at low levels, the effect of $\mathrm{Si}$ on the performance of the composite is lower than that of the $\mathrm{Mg}$ on the mechanical properties.

The resistivity of the composites under $1 w / \%$ carbon fiber with different $\mathrm{Mg}$ and $\mathrm{Si}$ contents is shown in Figure 9. The results show that with the increase of $\mathrm{Mg}$, the resistivity of the $1 \mathrm{w} / \% \mathrm{Cf} / \mathrm{Al}-5 \mathrm{Cu}$ composites showed a downward trend. The resistivity of the composites added with $0.3 \% \mathrm{Mg}$ was $18.4 \mu \Omega / \mathrm{mm}$. It is lower than that of the original material by $55 \%$. With the increase of $\mathrm{Si}$, the resistivity of the composites exhibits an opposite upward trend. When the same mass fraction of Si was

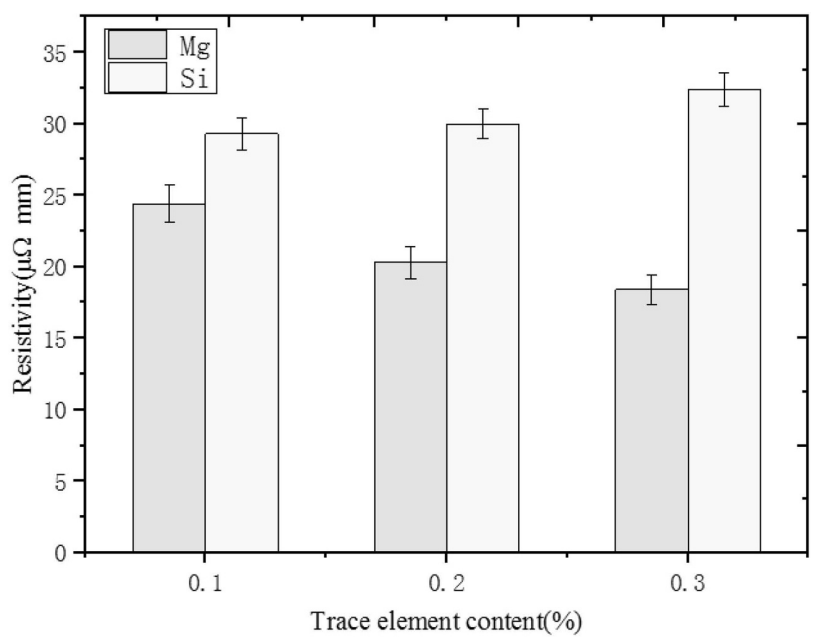

Figure 9: Resistivity of $\mathrm{Cf} / \mathrm{Al}-5 \mathrm{Cu}$ composites with different $\mathrm{Mg}$ and Si contents added, the resistivity of the composites was $32.4 \mu \Omega / \mathrm{mm}$. It is higher than that of the original matrix by $13 \%$. This means that the conductivity of the material deteriorates.

This is because the $\mathrm{Mg}$ is distributed in the matrix with a dispersed form. This form increases the scattering of electrons in the propagation. Therefore, the addition of the $\mathrm{Mg}$ can significantly increase the electrical conductivity, thereby lowering the electrical resistivity. However, Si adversely affects the conductivity of the aluminum alloy conductor. In addition, $\mathrm{Si}$ also affects the casting properties and creates defects. Through the above analyses, the addition of $\mathrm{Si}$ leads to a decrease in the electrical conductivity, and the resistivity increases.

\subsection{Microstructure observation and analysis}

Above analyses show that the mechanical and electrical properties of the composite were the best by adding $0.3 \% \mathrm{Mg}$ element and $1 \mathrm{w} / \%$ carbon fiber. So, it is necessary to observe the microstructure of the composite with $0.3 \% \mathrm{Mg}$ and $1 \mathrm{w} / \%$ carbon fiber. As shown in Figure 10, it indicates that the fibers are arranged in the direction of suction. The $\mathrm{Cf} / \mathrm{Al}-5 \mathrm{Cu}$ composites prepared by the VSC method have a uniform distribution. There are no obvious fiber agglomeration, breakage and drift phenomenon. The composite material has no defects such as shrinkage, cracks and voids. The carbon fibers were distributed in the axial section of the specimens.

As shown in Figure 11, the carbon fiber is mainly distributed in the grain boundary of the matrix alloy. Carbon fiber appears as a composite reinforcement in the material. The addition of carbon fibers makes the metal matrix undergo secondary phase strengthening, dislocation strengthening, and fine grain strengthening during the forming process. Therefore, the performance of the material is improved. However, the carbon fiber and the metal matrix produce an interfacial reaction during the casting process. Thereby, $\mathrm{Al}_{4} \mathrm{C}_{3}$ phases were produced in

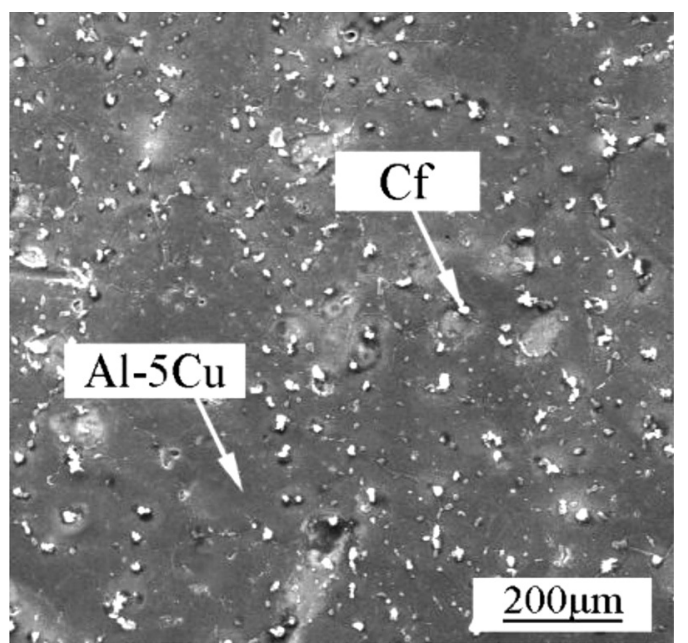

Figure 10: Microstructure morphology within the cross-section of the Cf/Al-5Cu composites with $1 \mathrm{w} / \%$ carbon fiber and $0.3 \% \mathrm{Mg}$ 


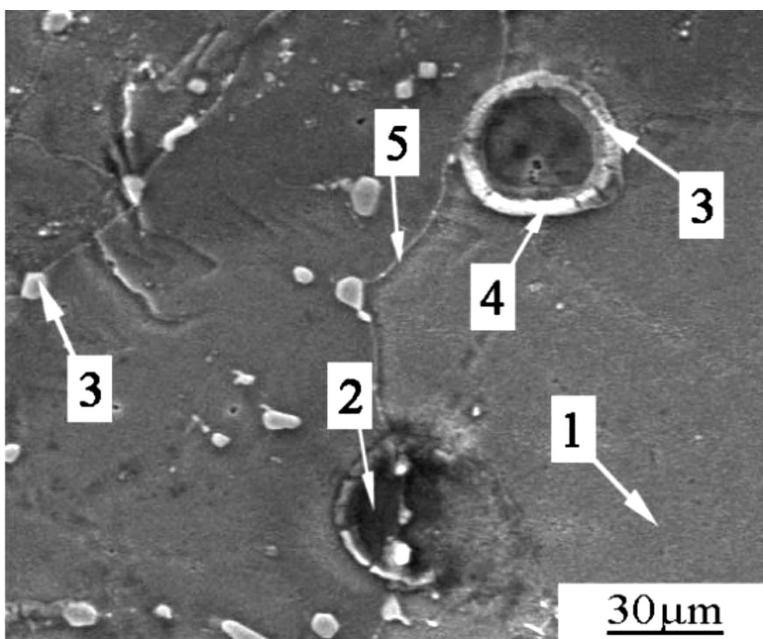

Figure 11: Microstructure morphology within the cross-section of $\mathrm{Cf}$ / $\mathrm{Al}-5 \mathrm{Cu}$ composite with $1 \mathrm{w} / \%$ carbon fiber and $0.3 \% \mathrm{Mg}(1-\mathrm{Al}-5 \mathrm{Cu}$; 2-Cf; 3- $\mathrm{Al}_{4} \mathrm{C}_{3} ; 4-\mathrm{Mg} ; 5-G r a i n$ boundary)

the vicinity of the carbon fibers. ${ }^{19,20}$ Part of the $\mathrm{Al}_{4} \mathrm{C}_{3}$ phase is formed on the surface of the carbon fiber. Part of the $\mathrm{Al}_{4} \mathrm{C}_{3}$ phase is distributed away from the carbon fibers in the composite matrix.

It can also be observed that the $\mathrm{Mg}$ is distributed on the surface of the carbon fiber. ${ }^{21}$ This is because that the negative mixed enthalpy of $\mathrm{Mg}$ and $\mathrm{C}$ is the highest. ${ }^{22,23}$ And $\mathrm{Mg}$ is easily bonded to the carbon fiber, so that $\mathrm{Mg}$ is found near the carbon fiber. The proper amount of $\mathrm{Mg}$ not only benefits the aluminum alloy matrix, but also improves the wettability of the carbon fiber and the aluminum. And it improves the combination of the carbon fiber and the aluminum. By adding $\mathrm{Mg}$ in the $\mathrm{Cf} / \mathrm{Al}-5 \mathrm{Cu}$ composite, the interface strength between the carbon fiber and the aluminum alloy can be effectively improved.

\section{CONCLUSIONS}

1) The VSC method can be applied to the preparation of $\mathrm{Cf} / \mathrm{Al}-5 \mathrm{Cu}$ composites by selecting appropriate process parameters, including the melting temperature, the suction-hole diameter and the suction casting pressure.

2) The mechanical properties and electrical conductivity of the composite increase with increasing carbon fiber content. When the carbon fiber content is $2 \%$, the microhardness reaches $112.6 \mathrm{HV}$ and the tensile strength of $\mathrm{Cf} / \mathrm{Al}-5 \mathrm{Cu}$ reaches $258.7 \mathrm{MPa}$. The resistivity is 26.5 $\mu \Omega / \mathrm{mm}$.

3) Both Mg and Si can improve the mechanical properties of the material. And $\mathrm{Mg}$ improved the mechanical properties of the material, which is better than that of $\mathrm{Si}$. When the $\mathrm{Mg}$ content is $0.3 \%$, the tensile strength of $\mathrm{Cf} / \mathrm{Al}-5 \mathrm{Cu}$ is the highest. The microhardness reaches 128.3 HV. And the tensile strength reaches 294.7 MPa, which is $38.2 \%$ higher than that of $\mathrm{Cf} / \mathrm{Al}-5 \mathrm{Cu}$ without addition. At the same time, $\mathrm{Mg}$ increases the electrical conductivity of the material. However, as the Si content increases, the resistivity of the material increases, and the electrical conductivity of the composite material decreases accordingly.

4) The carbon fibers were arranged within the composite material along the direction of gravity and suction coupling after VSC. The carbon fibers were evenly distributed in the grain boundary of the composite material. $\mathrm{By}$ adding $\mathrm{Mg}$ to the $\mathrm{Cf} / \mathrm{Al}-5 \mathrm{Cu}$ composite, the interface strength between the carbon fiber and the aluminum alloy can be effectively improved.

\section{Acknowledgements}

This project is funded by National Key Research and Development Program of China (Grant No. 2018YFB1307900), Key Research Program of Shanghai Science and Technology Commission (Grant No. 16030501200), National Natural Science Foundation of China (Grant No.51805314). The Robot Functional Materials Preparation Laboratory in Shanghai University of Engineering Science is also gratefully acknowledged.

\section{REFERENCES}

${ }^{1}$ Z. Yunhe, W. Gaohui, Comparative study on the interface and mechanical properties of T700/Al and M40/Al composites, Rare Metals, 1 (2010), 102-107, doi:10.1007/s12598-010-0018-2

${ }^{2}$ W. Hufenbach, M. Gude, A. Czulak, F. Engelmann, K. J. Kurzydlowski, J. Sleziona, Characterisation of CF/AL-MMC manufactured by means of gas pressure infiltration, Materials Science Forum, 690 (2011), 116-120, doi:10.4028/www.scientific.net/MSF. 690.116

${ }^{3}$ R. Caliman, Aspects regarding wearing behavior in case of aluminium composite materials reinforced with carbon fibers, IOP Conference Series: Materials Science and Engineering, 145 (2016), 013-072, doi:10.1088/1757-899X/145/7/072013

${ }^{4}$ K. Feng, H. Chen, J. Xiong, Z. Guo, Investigation on diffusion bonding of functionally graded $\mathrm{WC}-\mathrm{Co} / \mathrm{Ni}$ composite and stainless steel, Materials \& Design, 46 (2013), 622-626, doi:10.1016/j.matdes. 2012.11.006

${ }^{5}$ B. Bhav. Singh, M. Balasubramanian, Processing and properties of copper-coated carbon fibre reinforced aluminium alloy composites, Journal of Materials Processing Technology, 4 (2009), 2104-2110, doi:10.1016/j.jmatprotec.2008.05.002

${ }^{6}$ H. Ali.Alhashmy, M. Nganbe, Laminate squeeze casting of carbon fiber reinforced aluminum matrix composites, Materials \& Design, 67 (2015), 154-158, doi:10.1016/j.matdes.2014.11.034

${ }^{7}$ Y. Hu, F. Luo, S. Duan, W. Zhou, D. Zhu, Mechanical and dielectric properties of $\mathrm{SiCf} / \mathrm{SiC}$ composites fabricated by PIP combined with CIP process, Ceramics International, 42 (2016), 6800-6806, doi:10.1016/j.ce ramint.2016.01.057

${ }^{8}$ Y. Q. Ma, L. H. Qi, T. Zhang, J. M. Zhou, G. Z. Yao, Study on defects of 2D-Cf/Al composite prepared by liquid solid extrusion following vacuum infiltration technique, International Journal of Advanced Manufacturing Technology, 88 (2017), 89-96, doi:10.1007/ s00170-016 -8768-0

${ }^{9}$ Y. Q. Ma, L. H. Qi, J. M. Zhou, T. Zhang, H. J. Li, Effects of process parameters on fabrication of 2D-Cf/Al Composite Parts by liquid-solid extrusion following the vacuum infiltration technique, Metallurgical \& Materials Transactions B, 48 (2016), 1-9, doi:10.1007/ s11663-016-0814-7

${ }^{10}$ T. He, H. J. Liu, X. J. Shi, Y. M. Huo, L. Min, T. T. Pan, Effect of Si and $\mathrm{Mn}$ on microstructure and mechanical properties of vacuum suction casting Al-4.5Cu Alloy, Strength of Materials, 4 (2018), 665-673, doi:10.1007/s11223-018-0011-9 
${ }^{11}$ Z. G. Liu, X. B. Mang, L. H. Chai, Y. Y. Chen, Interface study of carbon fibre reinforced Al-Cu composites, Journal of Alloys \& Compounds, 504 (2010), 512-514, doi:10.1016/j.jallcom.2010.04.081

${ }^{12}$ S. R. Bakshi, A. K.Keshri, V. Singh, S.Seal, A. Agarwal, Interface in carbon nanotube reinforced aluminum silicon composites: Thermodynamic analysis and experimental verification, Journal of Alloys And Compounds, 1 (2009), 207-213, doi:10.1016/j.jallcom. 2009.03.055

${ }^{13}$ C. Wang, G. Chen, X. Wang, Y. Zhang, W. Yang, G. Wu, Effect of $\mathrm{Mg}$ content on the thermodynamics of interface reaction in $\mathrm{Cf} / \mathrm{Al}$ composite, Metallurgical And Materials Transaction Physical Metallurgy And Materials Science, 7 (2012), 2514-2519, doi:10.1007/ s11661-012-1090-Z

${ }^{14}$ T. T. Pan, T. He, Y. M. Huo, X. J. Shi, S. S.Chen, K. P. Yu, A. N. Sun, Effect of the processing parameters on the microstructure and properties of the ZL116 aluminium alloy after vacuum suction casting, Material Intechnology, 6 (2018), 795-801, doi:10.17222/ mit.2018.094

${ }^{15}$ X. C. Ye, W. G. Zhao, The study on TiAl based alloy blade casting structure by bottom pouring vacuum suction casting, Applied Mechanics \& Materials, 442 (2014), 44-47, doi:10.4028/www.scientific.net/amm. 442.44

${ }^{16}$ E. Lee, B. Mishra, Effect of cooling rate on the mechanical properties of AA365 aluminum alloy heat-treated under T4, T5, and T6 conditions, International Journal of Metal Casting, 2 (2017), 1-8, doi:10.1007/s40962-017-0195-y

${ }^{17}$ S. Baskaran, B. M. M. Selvan, V.Anandakrishnan, R.Venkatraman, M. Duraiselvam, Effect of heat treatment on wear behavior of hot extruded AA7075-4\% TiC in situ metal matrix composite, Applied Mechanics \& Materials, 541 (2014), 263-267, doi:10.4028/www.scientific.net/AMM.541-542.263
${ }^{18}$ S. Ren, X. He, X. Qu, I. S.Humail, Y. Li, Effect of Mg and Si in the aluminum on the thermo-mechanical properties of pressureless infiltrated $\mathrm{SiCp} / \mathrm{Al}$ composites(Article), Composites Science and Technology, 10 (2007), 2103-2113, doi:10.1016/j.compscitech.2006. 11.00

${ }^{19}$ A. M. K.Esawi, K. Morsi, A. Sayed, A. A. Gawad, P. Borah, Fabrication and properties of dispersed carbon nanotube-aluminum composites, Materials Science \& Engineering A, 508 (2009), 167-173, doi:10.1016/j.msea.2009.01.002

${ }^{20}$ K. Morsi, A. M. K.Esawi, P. Borah, S. Lanka, A. Sayed, Characterization and spark plasma sintering of mech-anically milled aluminum-carbon nanotube (CNT) composite powders, Journal of Composite Materials, 44 (2010), 1991-2003, doi:10.1177/ 0021998310361990

${ }^{21}$ J. Zhang, S. Liu, Y. Zhang, Y. Dong, Y. Liu, T. Li, Fabrication of woven carbon fibers reinforced $\mathrm{Al}-\mathrm{Mg}(95-5 \mathrm{wt} \%)$ matrix composites by an electromagnetic casting process, Journal of Materials Processing Technology, 226 (2015), 78-84, doi:10.1016/j.jmatprotec.2015. 06.040

${ }^{22}$ J. Rams, A. Ureña, M. D.Escalera, M. Sanchez, Electroless nickel coated short carbon fibres in aluminium matrix composites, Composites Part A, 38 (2007), 566-575, doi:10.1016/j.compositesa.2006. 02.010

${ }^{23}$ X. Yang, Y. Zhang, Prediction of high-entropy stabilized solid-solution in multi-component alloys, Materials Chemistry \& Physics, 132 (2012), 233-238, doi:10.1016/j.matchemphys.2 011.11.021 